\title{
Soft tissue thickness values for Black and Coloured South African children aged 6 to 13 years
}

\author{
N. Briers ${ }^{\mathrm{a}}$, T.M. Briers ${ }^{\mathrm{b}}$, P.J. Becker ${ }^{\mathrm{c}, \mathrm{d}}$, M. Steyn ${ }^{\mathrm{a}}$
}

${ }^{a}$ Forensic Anthropology Research Centre, Department Anatomy, School of Medicine, Faculty of Health Sciences, University of Pretoria, South Africa

${ }^{\mathrm{b}}$ Victim Identification Unit, Forensic Science Laboratory, South African Police Service

${ }^{\mathrm{c}}$ Biostatistics Unit, Medical Research Council, South Africa

${ }^{d}$ Research Office, Faculty of Health Sciences, University of Pretoria, South Africa

\author{
Corresponding author: \\ N Briers \\ Department Anatomy, School of Medicine, Faculty of Health Sciences, University of Pretoria \\ Private Bag x323 \\ Arcadia \\ Pretoria \\ 0007 \\ Republic of South Africa \\ Tel: +27123192631 \\ Fax: +27123192240 \\ E-mail: nanette.briers@up.ac.za
}

\section{Highlights}

- Population data for facial soft tissue thickness (STT) of Black and Coloured South African children are provided for facial reconstruction / approximation of juvenile remains.

- STT data should be pooled as two age groups subdivided at age 10 with ancestry taken into account.

- Sex should not be considered as it seems not to impact STT with more than $2 \mathrm{~mm}$ at any landmark.

- STTs in Coloured children are generally larger than in Black children.

\begin{abstract}
In children, craniofacial changes due to facial growth complicate facial approximations and require specific knowledge of soft tissue thicknesses (STT). The lack of South African juvenile STT standards of particular age groups, sex and ancestry is problematic. According to forensic artists in the South African Police Service the use of African-American values to reconstruct faces of Black South African children yields poor results. In order to perform a facial approximation that presents a true reflection of the child in question, information regarding
\end{abstract}


differences in facial soft tissue at different ages, sexes and ancestry groups is needed. The aims of this study were to provide data on STT of South African Black and Coloured children and to to assess differences in STT with respect to age, sex and ancestry. STT was measured using cephalograms of South African children $(n=388)$, aged $6-13$ years. After digitizing the images, STT measurements were taken at ten mid-facial landmarks from each image using the iTEM measuring program. STT comparisons between groups per age, sex and ancestry were statistically analyzed. The results showed that STT differences at lower face landmarks are more pronounced in age groups per ancestry as opposed to differences per age and sex. Generally, an increase in STT was seen between 6 - 10 year old groups and 11 -13 year old groups, regardless of ancestry and sex, at the midphiltrum, labiale inferius, pogonion, and beneath chin landmarks. This research created a reference dataset for STT of South African children of Black and Coloured ancestry per age and sex that will be useful for facial reconstruction / approximation of juvenile remains.

Keywords: Craniofacial reconstruction; craniofacial approximation; tissue thickness; children; South African population; Forensic Anthropology Population Data

\section{Introduction}

Craniofacial identification, whether it is used in the context of adults or children, requires intimate knowledge of human craniofacial anatomy and soft tissue thickness (STT). The South African Police Services (SAPS) annual crime statistics of the last 5 years have shown that the greatest frequency of cases regarding neglect and ill treatment of children had occurred in Gauteng (26.7\%) and the Western Cape provinces of South Africa (18.3\%) [1,2]. The Medical Research Council of South Africa determined that fatal child abuse, abandonment of babies and violence among teenage boys were the main causes for murder among children between the ages of 0 and 17 years. In terms of age specific murders, it was found that in the category of $0-4$ years, girls were more often murdered than boys. After age 4, the murder rate among boys increased [3]. Statistics obtained from the Forensic Anthropology Research Centre, situated in the Gauteng Province of South Africa, showed that 56 skeletons / decomposed bodies of subadults were analysed in the past 10 years.

Facial approximation / reconstruction of South African children from European ancestry can be based on European STT standards as a study on White British children by Wilkinson [4] showed good correlation to results from Manhein et al. [5] on White North American children. 
The same may not be true for Black South African children. In a study by Cavanagh and Steyn [6], clear differences were found between STT's of South African and North American black females.

Coloured children also pose a problem as Philips and Smuts [7] found significant differences when they compared STT of adult Black South Africans to a Coloured adult sample. Coloured people in the Western Cape are descendants of the Khoesan, Malaysian slaves brought in by the Dutch, and local African and European people, while the Black people in Gauteng are descendants of the people who migrated and dispersed from the northern parts of Africa [8-10].

Data on STT of children are on the increase in the literature, but it mainly involves American children of European $[5,11,12]$ and African [5,13] descent. Three studies on children from countries other than the USA were found and included Hispanic [5], White British [4] and female Japanese children [14,15]. Data on STT for South African children are still absent in the scientific literature and adult data cannot be used as studies have shown that STT changes with age, especially between the ages of 6 and $13[4,16]$.

A variety of methods have been used in order to obtain STT data, each with its own strengths and shortcomings. In terms of ultrasound, an experienced ultrasonographer or radiologist is required and children may not be as compliant as adults [17-19]. It is also time consuming, as it needs to be ascertained that there is no compression of the soft tissue overlying the bony landmark which can cause inaccurate measurements. CT / MRI scans are said to be more accurate for the measurement of STT when compared to needle puncture of cadaver material $[6,7,20,21]$. The advantages of the imaging methods include the ability to work on living individuals with minimal distortion of STT and high resolution of soft tissue with CT scanning [4]. The disadvantages include some exposure to radiation when using the radiographic method; inaccurate or improper positioning of the transducer due to inexperience when using ultrasound; and both high cost and radiation involved in CT and MR scanning [22]. During scanning patients are also usually in a supine position, whereas an upright position is preferable. In using images already available in a database at a radiology department or the local academic hospital, researchers can circumvent radiation and cost issues of cephalograms, CT scans and MR imaging.

According to Smith and Throckmorton [17], different methods can render different measurements. These authors used ultrasound and radiographs obtained at three locations to compare three sets of STT measurements. They found that the correlation between measurements from the radiographs and ultrasound ranged from poor to excellent and the 
difference between measured STT ranged from $-5.0 \mathrm{~mm}$ to $+3.0 \mathrm{~mm}$, which they attributed to difficulty in location of specific landmarks and in position of the head [17]. A further analysis of different methods used to collect the STT data showed that data from cephalograms produced larger values for mid-facial landmarks. The second and third largest values were found in studies that used ultrasound on living individuals and needle puncture on cadaver material, respectively. Both the latter two methods produced comparable results, except at some bilateral landmarks which may be due to positioning of the individual (supine $v s$ upright). CT and MRI values produced the lowest discrepancies [18]. Stephan and Simpson [18] have shown that even though differences in methodology render different values, these values often do not differ significantly in terms of statistical or practical application. In a review, they compared a pooled set of STT data from different authors and with different methods, such as needle puncture, ultrasound, cephalograms, CT and MRI, to ascertain practical differences. None of these methods, when used by different authors, were shown to produce a consistent result. They concluded that, regardless of the strengths and weaknesses of each method, one method was not superior to the other. They suggested that STT data be pooled without considering the different methodologies [18,23-25]. Recent studies favored either ultrasound [16] or CT [20,21].

The aim of this study was to provide STT data for South African children aged 6 to 13 years as a means to improve the reliability and validity of craniofacial approximations / reconstruction for children. Specifically, differences in STT with respect to age, sex and population of origin were assessed. We also tried to determine if there was a way in which data for different age groups could be sensibly combined, as we may not know the exact age of a child skull which needs reconstruction.

\section{Materials and Methods}

For this study, a cross-sectional, descriptive study design was used, in order to collect data from South African children of different ancestry (African/Black and Coloured). Although a variety of different techniques and methods are available for measurement of STT and facial dimensions as explained above, this study made use of cephalograms for measuring midline facial STT as not enough CT scans of children were available at the local academic hospital to meet the sample size criteria. A cephalogram is a specific type of lateral radiograph of the face that shows both the skeletal profile and soft tissue outline of dental patients. Cephalograms are routinely used to determine dental occlusion in order to plan orthodontic treatment. Therefore cephalograms are taken by an experienced radiographer with the head in a standardized position 
to avoid rotation. Unfortunately cephalograms only enables visualization of midline STT and as a result, only midline STTs were measured in cephalograms.

The communities where the children were sampled from were selected based on three criteria: Relethford's geographical cluster axiom [26] which was developed from work by Cavelli-Sforza [27] and Lieberman and Kirk [28]; communities most affected from crime that involved children; and compliance of oral and dental hospitals.

Relethford's [26] axiom dictates that geographical clusters express the correlation between genetics and geography and that the geographical distances between clusters should exceed the geographical distance within a cluster. In practical terms, oral and dental hospitals within the Western Cape and Gauteng provinces were identified to participate in the project as the geographical distance between these two provinces is $1200 \mathrm{~km}$. However, homogeneous groups, consisting only of one ancestral group, could not be guaranteed as the researchers had to rely on data from files. Therefore, some Coloured children may inadvertently be contained within the Black group and vice versa.

Ethical clearance was obtained from the Main Ethics and Research Committee, Faculty of Health Science, University of Pretoria (85/2007) prior to commencement of this study. Only patient images and data already on file were reviewed and captured. The STT data were collected retrospectively from these files which did not contain information regarding the weight and height of the children. Therefore, the effect of BMI on STT could not be assessed. A total of 388 cephalograms from children aged 6 to 13 years of Black and Coloured ancestry were obtained from oral and dental hospitals in the Western Cape and Gauteng. STT measurements were taken at 10 mid-facial landmarks using iTEM morphometry software (iTEM Analyses imaging program; Olympus Soft Imaging Solutions, 48149 Münster, Germany) (Fig. 1).

Landmarks on the skull were located and digitally marked. Table 1 shows a list of homologous landmarks. The method for measuring STT is similar to methods described by Aulsebrook et al. [29] and Cavanagh and Steyn [6]. First, a tangential line was placed on the curvature of the bony landmark's outer surface on the skull. Another line was then drawn perpendicularly to the tangential line. This line was extended to the point where the outline facial profile was visible. This distance was measured as the STT. The orientation of the line was standardized based on the descriptions provided in Table 1. 


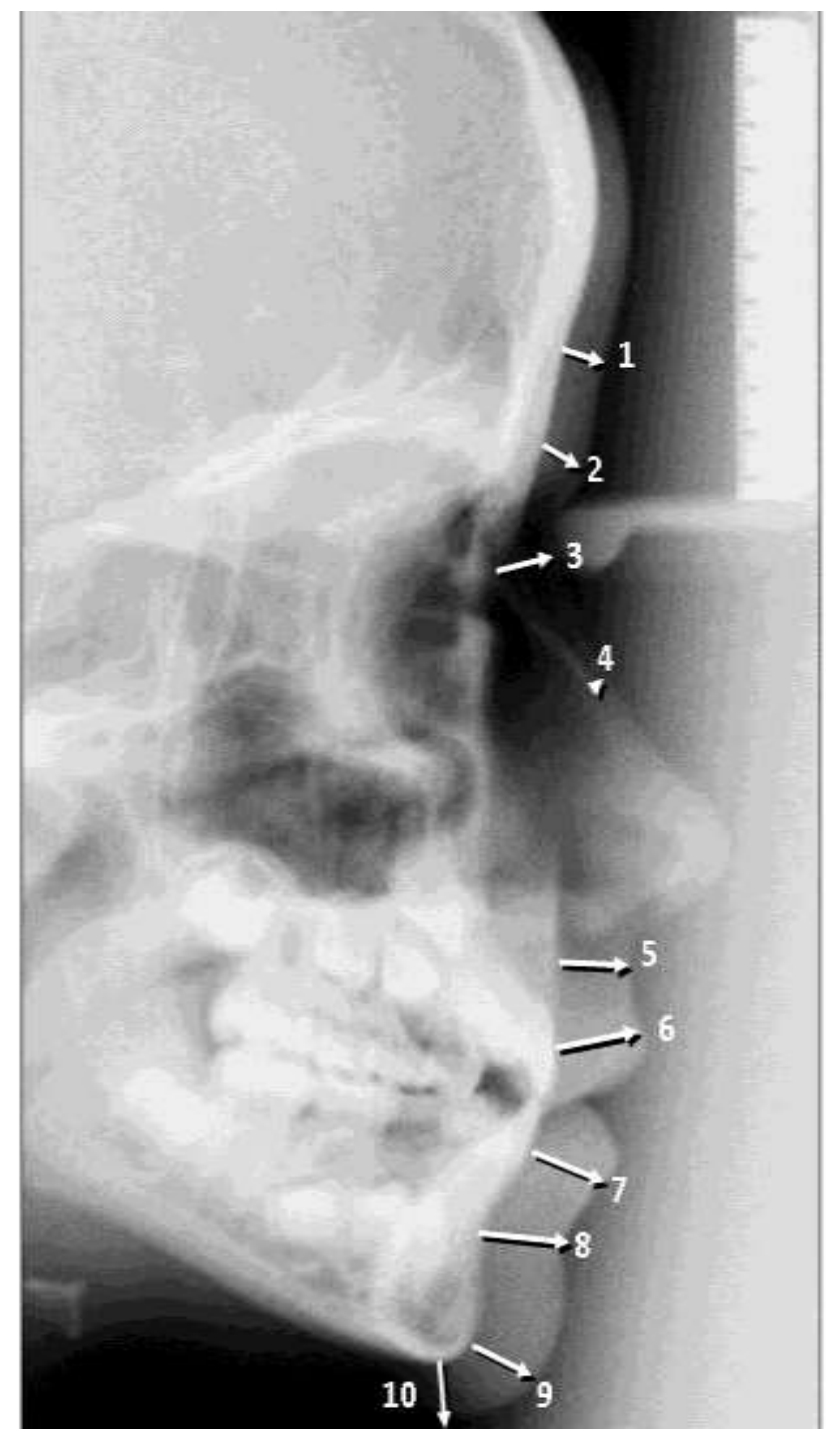

Fig. 1. Cephalogram indicating the landmarks at which tissue thickness was measured (1: Supraglabella; 2: Glabella; 3: Nasion; 4: End nasal; 5: Midphiltrum; 6: Labiale superius; 7: Labiale inferius; 8: Labiomentale; 9: Pogonion; 10: Menton).

The distance was automatically registered on a spreadsheet. As a means to calibrate the measuring programme, all cephalograms were first digitized with a scale. In order to test intraobserver and inter-observer reliability for STT, 27 cephalograms were selected at random and the linear distances were re-measured. Both intra-observer and inter-observer repeatability were calculated as the intra-cluster correlation and inter-rater agreement respectively, which is restricted to 1 . A value close to 1 indicates a high reliability. The reliability for both measuring events by the first author and the second observer varied between acceptable levels of 0.9924 and 0.9999 . 


\section{Table 1}

List of landmarks and their definitions of hard and soft tissue landmarks [5,23,29,40, 41].

\begin{tabular}{|c|c|c|c|c|c|}
\hline $\begin{array}{c}\text { Skeletal } \\
\text { landmark }\end{array}$ & Symbol & Description & $\begin{array}{l}\text { Soft tissue } \\
\text { landmark }\end{array}$ & Symbol & Description \\
\hline Supraglabella & $\mathrm{sg}$ & $\begin{array}{l}\text { Point at the deepest part of } \\
\text { the curvature on the frontal } \\
\text { bone }\end{array}$ & Supraglabella & sg' & $\begin{array}{l}\text { Midline soft tissue point } \\
\text { directly overlying hard } \\
\text { tissue of the supraglabella }\end{array}$ \\
\hline Glabella & g & $\begin{array}{l}\text { The most prominent point } \\
\text { between the supraorbital } \\
\text { ridges in the midsagittal } \\
\text { plane }\end{array}$ & Glabella & g' & $\begin{array}{l}\text { Most anterior midline soft } \\
\text { tissue point overlying the } \\
\text { glabella }\end{array}$ \\
\hline Nasion & $\mathrm{n}$ & $\begin{array}{l}\text { The midpoint of the suture } \\
\text { between the frontal and the } \\
\text { two nasal bones }\end{array}$ & Nasion & n' & $\begin{array}{l}\text { Midline soft tissue point } \\
\text { directly overlying hard } \\
\text { tissue at the nasion }\end{array}$ \\
\hline $\begin{array}{c}\text { End nasal / } \\
\text { Rhinion }\end{array}$ & en / rhi & $\begin{array}{l}\text { The anterior tip of the nasal } \\
\text { bone OR Midline point at the } \\
\text { inferior free end of the } \\
\text { internasal suture }\end{array}$ & $\begin{array}{c}\text { End nasal / } \\
\text { Rhinion }\end{array}$ & en' / rhi' & $\begin{array}{l}\text { Midline soft tissue point } \\
\text { directly overlying the } \\
\text { hard tissue at the end of } \\
\text { the nasal point / rhinion }\end{array}$ \\
\hline $\begin{array}{l}\text { Midphiltrum } \\
\text { (point A) }\end{array}$ & $\mathrm{mp} / \mathrm{A}$ & $\begin{array}{l}\text { The deepest midline point } \\
\text { on the indentation } \\
\text { between the nasal spine } \\
\text { and the supradentale. } \\
\text { Also known as point A }\end{array}$ & Midphiltrum & $\mathrm{mp}^{\prime}$ & $\begin{array}{l}\text { Midline point midway } \\
\text { between soft tissue } \\
\text { subnasale and the } \\
\text { vermilion border of the } \\
\text { upper lip in the groove of } \\
\text { the philtrum }\end{array}$ \\
\hline $\begin{array}{l}\text { Upper lip border } \\
\text { (Labiale } \\
\text { superius) }\end{array}$ & ls & $\begin{array}{l}\text { The apex of the alveolus in } \\
\text { the midline between the } \\
\text { maxillary central incisors } \\
\text { (also the alveolare or } \\
\text { prosthion) }\end{array}$ & $\begin{array}{l}\text { Upper lip } \\
\text { border } \\
\text { (Labiale } \\
\text { superius) }\end{array}$ & ls' & $\begin{array}{l}\text { Midline soft tissue point } \\
\text { at the vermilion } \\
\text { border of upper lip }\end{array}$ \\
\hline $\begin{array}{l}\text { Lower lip } \\
\text { border } \\
\text { (Labiale } \\
\text { inferius) }\end{array}$ & $\mathrm{li}$ & $\begin{array}{l}\text { The apex of the alveolus } \\
\text { in the midline between } \\
\text { the mandibular central } \\
\text { incisors }\end{array}$ & $\begin{array}{l}\text { Lower lip } \\
\text { border } \\
\text { (Labiale } \\
\text { inferius) }\end{array}$ & $\mathrm{li}^{\prime}$ & $\begin{array}{l}\text { Midline soft tissue point } \\
\text { at the vermilion border of } \\
\text { lower lip }\end{array}$ \\
\hline $\begin{array}{l}\text { Labiomental } \\
\text { groove or } \\
\text { mentolabial } \\
\text { sulcus } \\
\text { (point B) }\end{array}$ & mls / B & $\begin{array}{l}\text { Deepest midline point in } \\
\text { the groove } \\
\text { superior to the mental } \\
\text { eminence. Also known as } \\
\text { point B }\end{array}$ & $\begin{array}{l}\text { Labiomental } \\
\text { groove or } \\
\text { mentolabial } \\
\text { sulcus }\end{array}$ & mls' & $\begin{array}{l}\text { Deepest soft tissue point } \\
\text { on the midline of the } \\
\text { groove just superior to the } \\
\text { chin }\end{array}$ \\
\hline Pogonion & $\mathrm{pg}$ & $\begin{array}{l}\text { The most anterior point in the } \\
\text { midline on the mental } \\
\text { protuberance }\end{array}$ & Pogonion & $\mathrm{pg}^{\prime}$ & $\begin{array}{l}\text { Most anterior midline } \\
\text { point on the eminence of } \\
\text { the soft tissue chin }\end{array}$ \\
\hline $\begin{array}{l}\text { Beneath chin } \\
\text { (menton) }\end{array}$ & me & $\begin{array}{l}\text { Most inferior midline } \\
\text { point at the mental } \\
\text { symphysis of the mandible } \\
\text { (also considered the most } \\
\text { causal point in the outline } \\
\text { of the mental symphysis } \\
\text { on radiographs) }\end{array}$ & $\begin{array}{l}\text { Beneath chin } \\
\text { (menton) }\end{array}$ & me' & $\begin{array}{l}\text { Midline soft tissue point } \\
\text { directly overlying the } \\
\text { hard tissue menton }\end{array}$ \\
\hline
\end{tabular}


Stephan and Simpson [23] argue that, as in the case of adult data, STT difference among sub-adults based on ancestry and sex is of little practical use, and can therefore be disregarded. This theory was tested by firstly pooling the STT data in ancestral groups with sex and age combined. Secondly, STT data from the current study were pooled into male and female groups with ancestry and age combined. Thirdly, the possible influence of age on STT data was assessed. Lastly, STT data of children aged 6 - 9 and $10-13$ years were pooled and analyzed according to age (ancestry and sex pooled); age subdivided by ancestry (sexes pooled) and age subdivided by sex (ancestry pooled).

After stratifying the data, standard descriptive statistics (including means, standard deviations) were calculated per age group, sex and ancestry. An analysis of variance (ANOVA) was used to assess differences in STT among age groups, sexes and ancestry groups.

ANOVA with Bonferroni comparisons were performed taking the factors sex, population and age categories into account. The Bonferroni comparison, also known as Dunn's multiple comparison procedure, was selected in order to avoid Type I error, which is the probability that significance is obtained by chance rather than real statistical difference [30]. Stephan et al. [27] also employed the Bonferroni correction in their analysis of multiple sets of STT data.

\section{Results}

Table 2 presents the sample composition of the sample per age and sex. About $42 \%$ of the sample comprised of children aged 12 - 13 years, as these are the ages children present to hospitals for possible orthodontic treatment (pers comm, A Hogan). Females seem to present earlier between the ages of 10 and 11, reaching peak numbers around 12 and 13 years of age. Usually patients are referred for dental assessment and treatment after eruption of most permanent teeth between 11 and 13 years, which explains the smaller number of patients in the young age category. From Table 3 it can be seen that 76.8\% (298/388) of the sample comprised of Coloured children who presented for oral and dental assessment and treatment. In comparison, $23.2 \%$ of the sample consisted of Black children (90/388). Table 3 shows that almost equal numbers of Black patients were present in all three age categories. Subsequent analyses were therefore in pooled groups as they each have meaningful sample sizes. 
Table 2

Composition of tissue thickness sample per age group and sex.

\begin{tabular}{|c|c|c|c|c|}
\hline \multirow{2}{*}{ Sex } & \multicolumn{3}{|c|}{ Age groups } & \multirow{2}{*}{ Total } \\
\hline & 6 to 9 years & $10 \& 11$ years & $11 \& 12$ years & \\
\hline Male & 47 & 49 & 57 & $153(39 \%)$ \\
\hline Female & 51 & 78 & 106 & $235(65 \%)$ \\
\hline Total & $\begin{array}{c}98 \\
(25 \%)\end{array}$ & $\begin{array}{c}127 \\
(33 \%)\end{array}$ & $\begin{array}{c}163 \\
(42 \%)\end{array}$ & $\begin{array}{c}388 \\
(100 \%)\end{array}$ \\
\hline
\end{tabular}

Table 3

Composition of tissue thickness sample per age group and ancestry.

\begin{tabular}{lcccc}
\hline \multirow{2}{*}{ Ancestry } & \multicolumn{3}{c}{ Age groups } & \multirow{2}{*}{ Total } \\
\cline { 2 - 4 } & $\mathbf{6}$ to 9 years & $\mathbf{1 0} \& \mathbf{1 1}$ years & $\mathbf{1 1} \& \mathbf{1 2}$ years & \\
\hline Black & 29 & 33 & 28 & $90(23 \%)$ \\
Coloured & 69 & 94 & 135 & $298(77 \%)$ \\
\hline \multirow{2}{*}{ Total } & $\mathbf{9 8}$ & $\mathbf{1 2 7}$ & $\mathbf{1 6 3}$ & $\mathbf{3 8 8}$ \\
& $(\mathbf{2 5 \% )}$ & $\mathbf{( 3 3 \% )}$ & $\mathbf{( 4 2 \% )}$ & $\mathbf{( 1 0 0 \% )}$ \\
\hline
\end{tabular}

In Table 4, the STT (mean, SD, 95\% CI and p-value for the $t$-test) is provided for Black and Coloured children. The mean age of Black and Coloured children was 10.3 and 11.9 years respectively. Comparison between the Black and Coloured children, with sex and age combined, showed that the STTs were significantly different at seven out of ten landmarks, i.e., glabella, nasion, end nasal, midphiltrum, labiale inferius, labiomentale and beneath the chin ( $t$-test, $\mathrm{p}$ $<0.05)$. The STT was larger at these landmarks in Coloured children compared to the Black children, except at the end nasal landmark, where the STT in the Black children was larger. The difference in STT between Black and Coloured children varied between $0.02 \mathrm{~mm}$ and $2.12 \mathrm{~mm}$. The largest difference occurred at the midphiltrum. The difference was smaller than $1 \mathrm{~mm}$ at most landmarks, except at the labiomentale where the STT in the Coloured children was 1.03 mm larger compared to the Black children, and at the midphiltrum where the STT was $2.12 \mathrm{~mm}$ larger in the Coloured children. 
Table 4

Tissue thickness for Black and Coloured children with age and sex combined.

\begin{tabular}{|c|c|c|c|c|c|c|c|c|}
\hline \multirow[t]{2}{*}{ Landmark } & \multirow{2}{*}{$\begin{array}{l}\text { Group } \\
\text { Black }\end{array}$} & \multirow{2}{*}{$\begin{array}{l}\mathbf{N} \\
90\end{array}$} & \multirow{2}{*}{$\begin{array}{l}\text { Mean } \\
4.88 \\
\end{array}$} & \multirow{2}{*}{$\begin{array}{l}\text { SD } \\
0.96\end{array}$} & \multicolumn{2}{|c|}{$\begin{array}{l}\text { 95\% Confidence } \\
\text { Interval }\end{array}$} & $\begin{array}{c}\text { T-test, } \\
\text { p-value }\end{array}$ & \multirow[t]{2}{*}{$\begin{array}{c}\text { Difference } \\
\text { in mm } \\
\text { (Black } \\
\text { minus } \\
\text { Coloured) }\end{array}$} \\
\hline & & & & & 4.679 & 5.079 & & \\
\hline \multirow[t]{3}{*}{ Supraglabella } & Coloured & 298 & 4.86 & 1.24 & 4.716 & 4.999 & 0.878 & 0.02 \\
\hline & Total & 388 & 4.86 & 1.18 & 4.745 & 4.980 & & \\
\hline & Black & 90 & 5.74 & 1.06 & 5.518 & 5.961 & & \\
\hline \multirow[t]{3}{*}{ Glabella } & Coloured & 298 & 6.08 & 1.43 & 5.921 & 6.247 & 0.034 & -0.35 \\
\hline & Total & 388 & 6.00 & 1.36 & 5.869 & 6.140 & & \\
\hline & Black & 90 & 4.96 & 1.16 & 4.718 & 5.205 & & \\
\hline \multirow[t]{3}{*}{ Nasion } & Coloured & 298 & 5.37 & 1.46 & 5.204 & 5.538 & 0.015 & -0.41 \\
\hline & Total & 388 & 5.28 & 1.41 & 5.136 & 5.417 & & \\
\hline & Black & 90 & 2.54 & 0.64 & 2.411 & 2.678 & & \\
\hline \multirow[t]{3}{*}{ End nasal } & Coloured & 298 & 2.21 & 0.70 & 2.128 & 2.287 & 0.000 & 0.34 \\
\hline & Total & 388 & 2.29 & 0.70 & 2.216 & 2.355 & & \\
\hline & Black & 90 & 10.63 & 2.50 & 10.105 & 11.151 & & \\
\hline \multirow[t]{2}{*}{ Midphiltrum } & Coloured & 298 & 12.74 & 3.17 & 12.384 & 13.106 & 0.000 & -2.12 \\
\hline & Total & 388 & 12.25 & 3.15 & 11.939 & 12.569 & & \\
\hline \multirow{3}{*}{$\begin{array}{l}\text { Labiale } \\
\text { superius }\end{array}$} & Black & 90 & 12.47 & 1.98 & 12.055 & 12.883 & & \\
\hline & Coloured & 298 & 12.39 & 2.29 & 12.132 & 12.653 & 0.774 & 0.08 \\
\hline & Total & 388 & 12.41 & 2.22 & 12.189 & 12.632 & & \\
\hline \multirow{3}{*}{$\begin{array}{l}\text { Labiale } \\
\text { inferius }\end{array}$} & Black & 90 & 12.83 & 2.10 & 12.392 & 13.271 & & \\
\hline & Coloured & 298 & 13.38 & 2.27 & 13.126 & 13.643 & 0.040 & -0.55 \\
\hline & Total & 388 & 13.26 & 2.24 & 13.033 & 13.479 & & \\
\hline \multirow{3}{*}{ Labiomentale } & Black & 90 & 10.83 & 1.68 & 10.482 & 11.184 & & \\
\hline & Coloured & 298 & 11.86 & 2.11 & 11.623 & 12.104 & 0.000 & -1.03 \\
\hline & Total & 388 & 11.62 & 2.06 & 11.419 & 11.830 & & \\
\hline \multirow{3}{*}{ Pogonion } & Black & 90 & 10.91 & 2.09 & 10.478 & 11.352 & & \\
\hline & Coloured & 298 & 10.80 & 2.64 & 10.495 & 11.096 & 0.694 & 0.12 \\
\hline & Total & 388 & 10.82 & 2.52 & 10.572 & 11.074 & & \\
\hline \multirow{3}{*}{ Beneath chin } & Black & 90 & 5.56 & 1.29 & 5.292 & 5.832 & & \\
\hline & Coloured & 298 & 6.13 & 1.67 & 5.942 & 6.323 & 0.003 & -0.57 \\
\hline & Total & 388 & 6.00 & 1.60 & 5.840 & 6.160 & & \\
\hline
\end{tabular}

Significant differences between groups are highlighted ( $t$-test, $\mathrm{p} \leq 0.05$ )

The STT per sex (mean, SD, 95\% CI and p-value for the $t$-test) is presented in Table 5. The mean age of males was 10.6 years and females 10.9 years. In general, STTs at most landmarks were larger in females compared to the males. However, the only significant differences were seen at the pogonion and beneath the chin $(t$-test, $\mathrm{p}<0.05)$. The difference in STT between males and 
females varied between $0.01 \mathrm{~mm}$ and $0.62 \mathrm{~mm}$, and even the values at the pogonion and beneath the chin landmarks are smaller than $1 \mathrm{~mm}$ (pogonion: $0.62 \mathrm{~mm}$ and beneath the chin: $0.42 \mathrm{~mm}$ ) which has little practical value [23].

\section{Table 5}

Tissue thickness for male and female children with age and ancestral groups combined.

\begin{tabular}{|c|c|c|c|c|c|c|c|c|}
\hline \multirow[t]{2}{*}{ Landmark } & \multirow{2}{*}{$\begin{array}{l}\text { Group } \\
\text { Male }\end{array}$} & \multirow{2}{*}{$\begin{array}{c}\mathbf{N} \\
\\
153\end{array}$} & \multirow{2}{*}{$\begin{array}{c}\text { Mean } \\
4.81\end{array}$} & \multirow{2}{*}{$\begin{array}{l}\text { SD } \\
\\
1.16\end{array}$} & \multicolumn{2}{|c|}{$\begin{array}{l}\text { 95\% Confidence } \\
\text { Interval }\end{array}$} & \multirow[t]{2}{*}{$\begin{array}{l}\text { T-test, p- } \\
\text { value }\end{array}$} & \multirow[t]{2}{*}{$\begin{array}{l}\text { Difference in } \\
\text { mm } \\
\text { (Male minus } \\
\text { Female) }\end{array}$} \\
\hline & & & & & 4.623 & 4.992 & & \\
\hline \multirow[t]{3}{*}{ Supraglabella } & Female & 235 & 4.90 & 1.20 & 4.744 & 5.052 & 0.462 & -0.09 \\
\hline & Total & 388 & 4.86 & 1.18 & 4.745 & 4.980 & & \\
\hline & Male & 153 & 5.99 & 1.25 & 5.788 & 6.188 & & \\
\hline \multirow[t]{3}{*}{ Glabella } & Female & 235 & 6.01 & 1.43 & 5.831 & 6.198 & 0.853 & -0.03 \\
\hline & Total & 388 & 6.00 & 1.36 & 5.869 & 6.140 & & \\
\hline & Male & 153 & 5.23 & 1.39 & 5.008 & 5.451 & & \\
\hline \multirow[t]{3}{*}{ Nasion } & Female & 235 & 5.31 & 1.42 & 5.124 & 5.489 & 0.599 & -0.08 \\
\hline & Total & 388 & 5.28 & 1.41 & 5.136 & 5.417 & & \\
\hline & Male & 153 & 2.26 & 0.67 & 2.153 & 2.368 & & \\
\hline \multirow[t]{3}{*}{ End nasal } & Female & 235 & 2.30 & 0.72 & 2.210 & 2.394 & 0.565 & -0.04 \\
\hline & Total & 388 & 2.29 & 0.70 & 2.216 & 2.355 & & \\
\hline & Male & 153 & 12.42 & 3.25 & 11.902 & 12.940 & & \\
\hline \multirow[t]{2}{*}{ Midphiltrum } & Female & 235 & 12.15 & 3.09 & 11.747 & 12.543 & 0.400 & 0.28 \\
\hline & Total & 388 & 12.25 & 3.15 & 11.939 & 12.569 & & \\
\hline \multirow{3}{*}{$\begin{array}{l}\text { Labiale } \\
\text { superius }\end{array}$} & Male & 153 & 12.48 & 2.27 & 12.119 & 12.843 & & \\
\hline & Female & 235 & 12.36 & 2.19 & 12.083 & 12.645 & 0.612 & 0.12 \\
\hline & Total & 388 & 12.41 & 2.22 & 12.189 & 12.632 & & \\
\hline \multirow{3}{*}{$\begin{array}{l}\text { Labiale } \\
\text { inferius }\end{array}$} & Male & 153 & 13.27 & 2.37 & 12.894 & 13.650 & & \\
\hline & Female & 235 & 13.25 & 2.15 & 12.969 & 13.522 & 0.910 & 0.03 \\
\hline & Total & 388 & 13.26 & 2.24 & 13.033 & 13.479 & & \\
\hline \multirow{3}{*}{ Labiomentale } & Male & 153 & 11.62 & 2.14 & 11.280 & 11.962 & & \\
\hline & Female & 235 & 11.63 & 2.01 & 11.368 & 11.886 & 0.976 & -0.01 \\
\hline & Total & 388 & 11.62 & 2.06 & 11.419 & 11.830 & & \\
\hline \multirow{3}{*}{ Pogonion } & Male & 153 & 10.45 & 2.29 & 10.081 & 10.813 & & \\
\hline & Female & 235 & 11.07 & 2.63 & 10.730 & 11.406 & 0.017 & -0.62 \\
\hline & Total & 388 & 10.82 & 2.52 & 10.572 & 11.074 & & \\
\hline \multirow{3}{*}{ Beneath chin } & Male & 153 & 5.74 & 1.59 & 5.491 & 5.998 & & \\
\hline & Female & 235 & 6.17 & 1.60 & 5.961 & 6.372 & 0.011 & -0.42 \\
\hline & Total & 388 & 6.00 & 1.60 & 5.840 & 6.160 & & \\
\hline
\end{tabular}

Significant differences between groups are highlighted ( $t$-test, $\mathrm{p} \leq 0.05)$ 
Table 6

Descriptive statistics and p-values of ANOVA comparisons with Bonferroni correction of tissue thickness for children in terms of age groups $6-10$ years and 11 to 13 years.

\begin{tabular}{|c|c|c|c|c|c|c|c|c|}
\hline \multirow{4}{*}{$\begin{array}{l}\text { Landmark } \\
\text { Supraglabella }\end{array}$} & \multirow{2}{*}{$\begin{array}{c}\text { Group } \\
6-10 y\end{array}$} & \multirow{2}{*}{$\begin{array}{c}\mathbf{N} \\
151\end{array}$} & \multirow{2}{*}{$\begin{array}{c}\text { Mean } \\
4.83\end{array}$} & \multirow{2}{*}{$\begin{array}{c}\text { SD } \\
1.30\end{array}$} & \multicolumn{2}{|c|}{$\begin{array}{l}\text { 95\% Confidence } \\
\text { Interval }\end{array}$} & \multirow[t]{2}{*}{$\begin{array}{l}\text { ANOVA, } \\
\text { p-value }\end{array}$} & \multirow{2}{*}{$\begin{array}{c}\text { Difference in mm } \\
\text { (older group } \\
\text { minus younger } \\
\text { group) }\end{array}$} \\
\hline & & & & & 4.619 & 5.037 & & \\
\hline & $11-13 y$ & 237 & 4.88 & 1.10 & 4.744 & 5.026 & 0.671 & 0.06 \\
\hline & Total & 388 & 4.86 & 1.20 & 4.681 & 5.031 & & \\
\hline \multirow{3}{*}{ Glabella } & $6-10 y$ & 151 & 6.06 & 1.57 & 5.804 & 6.309 & & \\
\hline & $11-13 y$ & 237 & 5.97 & 1.21 & 5.817 & 6.125 & 0.245 & -0.09 \\
\hline & Total & 388 & 6.01 & 1.39 & 5.810 & 6.217 & & \\
\hline \multirow{3}{*}{ Nasion } & $6-10 y$ & 151 & 5.32 & 1.31 & 5.108 & 5.530 & & \\
\hline & $11-13 y$ & 237 & 5.25 & 1.47 & 5.061 & 5.437 & 0.159 & -0.07 \\
\hline & Total & 388 & 5.28 & 1.39 & 5.084 & 5.483 & & \\
\hline \multirow{3}{*}{ End nasal } & $6-10 y$ & 151 & 2.28 & 0.74 & 2.162 & 2.398 & & \\
\hline & $11-13 y$ & 237 & 2.29 & 0.68 & 2.203 & 2.376 & 0.569 & 0.01 \\
\hline & Total & 388 & 2.28 & 0.71 & 2.182 & 2.387 & & \\
\hline \multirow{3}{*}{ Midphiltrum } & $6-10 y$ & 151 & 11.72 & 2.93 & 11.248 & 12.189 & & \\
\hline & $11-13 y$ & 237 & 12.59 & 3.25 & 12.179 & 13.011 & 0.008 & 0.88 \\
\hline & Total & 388 & 12.16 & 3.09 & 11.713 & 12.600 & & \\
\hline \multirow{3}{*}{$\begin{array}{l}\text { Labiale } \\
\text { superius }\end{array}$} & $6-10 y$ & 151 & 12.30 & 2.29 & 11.935 & 12.670 & & \\
\hline & $11-13 y$ & 237 & 12.48 & 2.17 & 12.201 & 12.757 & 0.488 & 0.18 \\
\hline & Total & 388 & 12.39 & 2.23 & 12.068 & 12.714 & & \\
\hline \multirow{3}{*}{$\begin{array}{l}\text { Labiale } \\
\text { inferius }\end{array}$} & $6-10 y$ & 151 & 12.79 & 2.48 & 12.395 & 13.192 & & \\
\hline & $11-13 y$ & 237 & 13.55 & 2.02 & 13.292 & 13.809 & 0.002 & 0.76 \\
\hline & Total & 388 & 13.17 & 2.25 & 12.843 & 13.501 & & \\
\hline \multirow{3}{*}{ Labiomentale } & $6-10 y$ & 151 & 11.28 & 2.10 & 10.946 & 11.620 & & \\
\hline & $11-13 y$ & 237 & 11.84 & 2.01 & 11.585 & 12.100 & 0.060 & 0.56 \\
\hline & Total & 388 & 11.56 & 2.05 & 11.266 & 11.860 & & \\
\hline \multirow{3}{*}{ Pogonion } & $6-10 y$ & 151 & 10.37 & 2.33 & 9.998 & 10.747 & & \\
\hline & $11-13 y$ & 237 & 11.11 & 2.59 & 10.778 & 11.442 & 0.004 & 0.74 \\
\hline & Total & 388 & 10.74 & 2.46 & 10.388 & 11.095 & & \\
\hline \multirow{3}{*}{ Beneath chin } & $6-10 y$ & 151 & 5.58 & 1.44 & 5.347 & 5.811 & & \\
\hline & $11-13 y$ & 237 & 6.27 & 1.65 & 6.058 & 6.480 & 0.000 & 0.69 \\
\hline & Total & 388 & 5.92 & 1.54 & 5.702 & 6.145 & & \\
\hline
\end{tabular}

Significant differences between groups are highlighted (ANOVA, $\mathrm{p} \leq 0.05$ ) y- years

When comparing age groups per year cohorts (sex and ancestral groups combined; not shown) significant differences were seen at the glabella, labiale superius, labiale inferius and pogonion. ANOVA testing showed statistically significant differences between 9 and 10 year old age groups at the supraglabella, glabella and labiomentale. Unexpectedly, STT at all three 
landmarks were larger for the 9 year old group compared to the 10 year old group and ranged between $0.69 \mathrm{~mm}$ and $1.32 \mathrm{~mm}$ and may represent random variation. Significant differences were also seen between the 10 and 13 year old groups at the labiale inferius and labiomentale. As expected, STT at these landmarks was larger in the 13 year old group compared to the 10 year old group. These differences are all less than $3 \mathrm{~mm}$ and the practical value of such small differences have been questioned [18,23-25]. In practical terms few significant differences were seen between age groups and the STT increased at only at two landmarks with age.

Because only minor differences were detected when STT values were assessed per age group, age groups were pooled with the division at age 10, creating a 6 - 10 year old group and an 11 to 13 year old group (Table 6). Significant differences between the 6 - 10 year olds and 11 - 13 year olds were seen at the labiale inferius, pogonion and beneath the chin. None of the differences were more than $0.76 \mathrm{~mm}$, showing that increases at these ages were slight.

When comparing the two ancestral groups using the two age cohorts (6 - 10 years and 11 13 years) significant differences were seen at seven of the ten landmarks. These included the glabella, end nasal, midphiltrum, labiale inferius, labiomentale, pogonion and beneath the chin. Differences were mostly small although becoming more pronounced around the mouth and chin (end nasal and glabella: $\leq 1 \mathrm{~mm} ;$, labiale inferius, labiomentale, pogonion and beneath the chin: between 1.0 and $1.6 \mathrm{~mm}$; midphiltrum: $2.7 \mathrm{~mm}$ ).

Comparison of between males and females in terms of age (6 - 10 year old group and 11 13 year old group) showed significant differences at five of the ten landmarks. Significant differences were seen mostly in the lower face region at the midphiltrum, labiale inferius, pogonion and beneath the chin (ANOVA, $\mathrm{p}<0.05$ ). Only at the pogonion was the actual difference more than $1 \mathrm{~mm}$; at the other landmarks. it was less than $1 \mathrm{~mm}$. In practice, it is difficult to determine sex from sub-adult juvenile remains and therefore STT differences between sexes may not be usable and do, in any case, seem to be small [31,32]

STT data per age group (6 - 10 year old group and 11 - 13 year old group) per ancestry (sexes pooled) are presented in Table 7. Comparisons between groups by means of ANOVA with Bonferroni corrections showed significant differences at the midphiltrum, labiale inferius, labiomentale, pogonion and beneath the chin.

At the midphiltrum, several significant differences were seen between the groups. Young Black females differed significantly from both young Coloured males and young Coloured females. Older Black females also differed significantly from both older Coloured males and older Coloured females. 
Table 7:

Descriptive statistics and p-values of ANOVA comparisons with Bonferroni correction of tissue thickness for children in terms of age ( 6 - 10 years and 11 to 13 years) and ancestry (sex combined)

\begin{tabular}{|c|c|c|c|c|c|c|c|c|}
\hline \multirow[t]{3}{*}{ Landmark } & \multirow{2}{*}{$\begin{array}{c}\text { Group } \\
\text { Black } 6-10 y\end{array}$} & \multirow{2}{*}{$\begin{array}{l}\mathbf{N} \\
46\end{array}$} & \multirow{2}{*}{$\begin{array}{c}\text { Mean } \\
4.74\end{array}$} & \multirow{2}{*}{$\begin{array}{c}\text { SD } \\
0.86\end{array}$} & \multicolumn{2}{|c|}{$\begin{array}{c}95 \% \\
\text { Confidence } \\
\text { Interval }\end{array}$} & \multirow[t]{2}{*}{$\begin{array}{c}\text { ANOVA, } \\
\text { p-value }\end{array}$} & \multirow{3}{*}{$\begin{array}{c}\begin{array}{c}\text { Difference in mm } \\
\text { (Older group } \\
\text { minus younger } \\
\text { group) }\end{array} \\
0.29\end{array}$} \\
\hline & & & & & 4.483 & 4.994 & & \\
\hline & Black 11 - 13y & 44 & 5.03 & 1.04 & 4.712 & 5.341 & & \\
\hline \multirow[t]{5}{*}{ Supraglabella } & Coloured 6 - 10y & 105 & 4.87 & 1.45 & 4.586 & 5.148 & \multirow[t]{3}{*}{0.714} & \multirow{2}{*}{-0.01} \\
\hline & Coloured $10-13 y$ & 193 & 4.85 & 1.12 & 4.694 & 5.011 & & \\
\hline & Total & 388 & 4.86 & 1.18 & 4.745 & 4.980 & & 0.27 \\
\hline & Black 6 - 10y & 46 & $5.55^{\mathrm{a}}$ & 1.07 & 5.229 & 5.862 & \multirow{5}{*}{0.020} & \multirow{2}{*}{0.40} \\
\hline & Black 11 - 13y & 44 & 5.94 & 1.02 & 5.631 & 6.252 & & \\
\hline \multirow[t]{5}{*}{ Glabella } & Coloured $6-10 y$ & 105 & $6.28^{\mathrm{a}}$ & 1.70 & 5.951 & 6.610 & & \multirow{2}{*}{-0.30} \\
\hline & Coloured $10-13 y$ & 193 & 5.98 & 1.25 & 5.801 & 6.154 & & \\
\hline & Total & 388 & 6.00 & 1.36 & 5.869 & 6.140 & & 0.09 \\
\hline & Black 6 - 10y & 46 & 4.99 & 1.00 & 4.696 & 5.288 & \multirow{5}{*}{0.087} & \multirow{2}{*}{-0.06} \\
\hline & Black $11-13 y$ & 44 & 4.93 & 1.32 & 4.528 & 5.332 & & \\
\hline \multirow[t]{5}{*}{ Nasion } & Coloured 6 - 10y & 105 & 5.46 & 1.41 & 5.189 & 5.735 & & \multirow{2}{*}{-0.14} \\
\hline & Coloured $10-13 y$ & 193 & 5.32 & 1.49 & 5.110 & 5.534 & & \\
\hline & Total & 388 & 5.28 & 1.41 & 5.136 & 5.417 & & -0.20 \\
\hline & Black 6 - 10y & 46 & 2.44 & 0.53 & 2.283 & 2.595 & \multirow{5}{*}{0.000} & \multirow{2}{*}{0.22} \\
\hline & Black $11-13 y$ & 44 & $2.66^{\mathrm{b}}$ & 0.73 & 2.435 & 2.876 & & \\
\hline \multirow[t]{5}{*}{ End nasal } & Coloured 6 - 10y & 105 & $2.21^{\mathrm{b}}$ & 0.80 & 2.055 & 2.366 & & \multirow{2}{*}{0.00} \\
\hline & Coloured $10-13 y$ & 193 & $2.21^{\mathrm{b}}$ & 0.64 & 2.115 & 2.296 & & \\
\hline & Total & 388 & 2.29 & 0.70 & 2.216 & 2.355 & & 0.21 \\
\hline & Black $6-10 y$ & 46 & $10.28^{c}$ & 2.58 & 9.516 & 11.049 & \multirow{5}{*}{0.000} & \multirow{2}{*}{0.71} \\
\hline & Black $11-13 y$ & 44 & $10.99^{\mathrm{c}}$ & 2.38 & 10.264 & 11.714 & & \\
\hline \multirow[t]{3}{*}{ Midphiltrum } & Coloured 6 - 10y & 105 & $12.35^{\mathrm{c}}$ & 2.86 & 11.795 & 12.901 & & 061 \\
\hline & Coloured $10-13 y$ & 193 & $12.96^{\mathrm{c}}$ & 3.32 & 12.490 & 13.432 & & 0.01 \\
\hline & Total & 388 & 12.25 & 3.15 & 11.939 & 12.569 & & 1.32 \\
\hline & Black 6 - 10y & 46 & 12.46 & 1.81 & 11.921 & 12.996 & & 002 \\
\hline & Black $11-13 y$ & 44 & 12.48 & 2.16 & 11.825 & 13.137 & & 0.02 \\
\hline $\begin{array}{l}\text { Labiale } \\
\text { sunerius }\end{array}$ & Coloured 6 - 10y & 105 & 12.23 & 2.47 & 11.756 & 12.713 & 0.824 & 0.24 \\
\hline & Coloured $10-13 y$ & 193 & 12.48 & 2.18 & 12.169 & 12.789 & & \\
\hline & Total & 388 & 12.41 & 2.22 & 12.189 & 12.632 & & 0.27 \\
\hline & Black $6-10 y$ & 46 & $12.14^{\mathrm{a}}$ & 2.12 & 11.515 & 12.775 & & 140 \\
\hline & Black 11 - 13y & 44 & $13.55^{\mathrm{a}}$ & 1.84 & 12.991 & 14.107 & & 1.40 \\
\hline $\begin{array}{l}\text { Labiale } \\
\text { inferius }\end{array}$ & Coloured 6 - 10y & 105 & 13.08 & 2.58 & 12.579 & 13.577 & 0.001 & 0.47 \\
\hline & Coloured $10-13 y$ & 193 & $13.55^{\mathrm{a}}$ & 2.06 & 13.258 & 13.844 & & 0.41 \\
\hline & Total & 388 & 13.26 & 2.24 & 13.033 & 13.479 & & 1.88 \\
\hline I. & Black $6-10 y$ & 46 & $10.37^{\mathrm{b}}$ & 1.60 & 9.895 & 10.844 & 0000 & 08 \\
\hline Lâviontentate & Black 11 - 13y & 44 & 11.32 & 1.63 & 10.822 & 11.814 & 0.000 & 0.93 \\
\hline
\end{tabular}




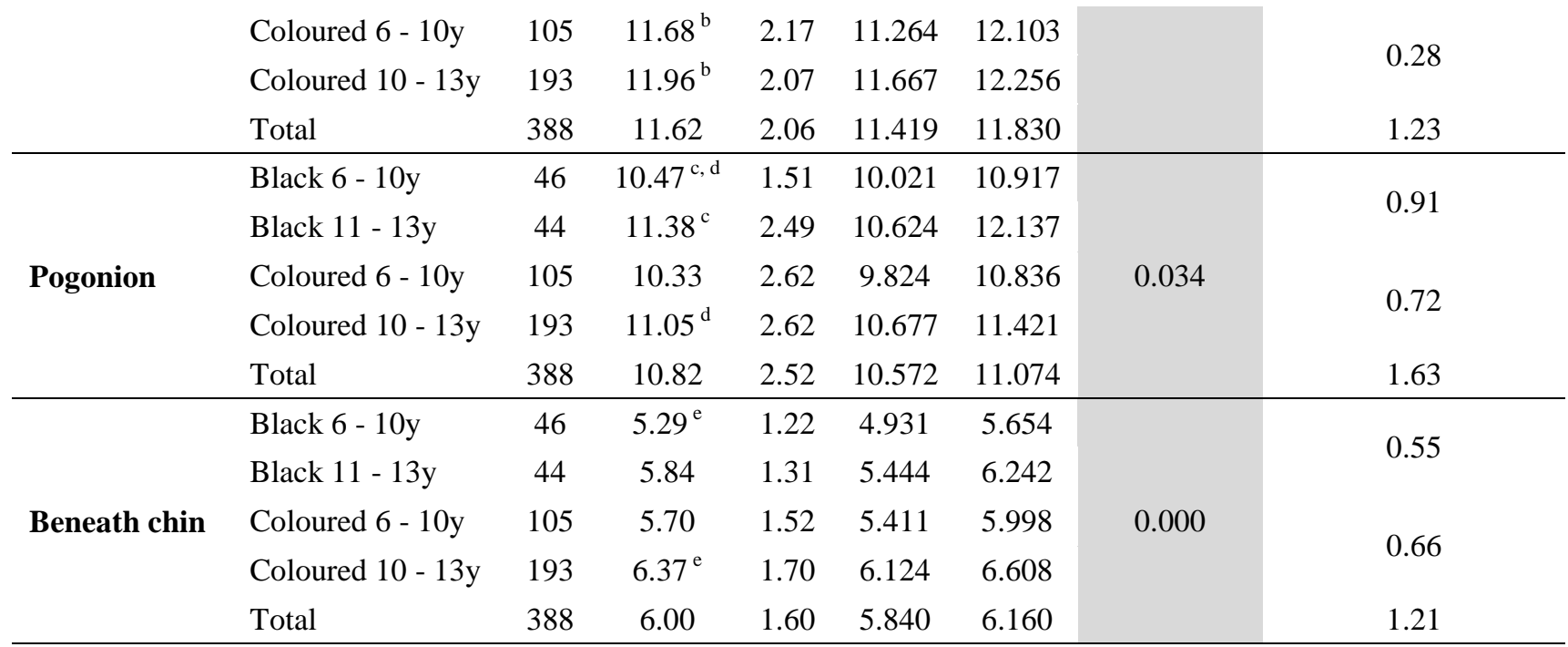

Significant differences between groups are highlighted (ANOVA, $\mathrm{p} \leq 0.05$ )

${ }^{\mathrm{a}-\mathrm{e}}$ Significant differences between specific groups (ANOVA, $\mathrm{p} \leq 0.05$ )

$\mathrm{y}-$ years

Only two groups differed significantly at the labiale inferius (young Black females and older Coloured males) and at the pogonion (young Coloured females and older Black females). At the labiomentale differences were seen between the young Black males and Coloured groups (young Black males vs young Coloured males; young Black males vs older Coloured males; young Black males vs older Coloured females, ANOVA, $\mathrm{p}<0.05$ ), the exception being the young Coloured females where no significant difference were detected as compared to young Black males. At the landmark beneath the chin significant differences were seen between the young Black males and older Coloured females as well as between the young and older Coloured females (ANOVA, p < 0.05). In summary, differences were mostly seen at landmarks involving the mouth and chin in females, while the STTs in Coloured children were generally larger that in Black children.

A general trend for an increase in STT between 6 - 10 year old groups, compared to the 11 13 year old groups, regardless of ancestry and sex, could be seen at most landmarks in the lower face region (midphiltrum, labiale inferius, pogonion, beneath chin). This trend suggests that STTs increase in younger children due to faster growth of facial soft tissues in the lower face, but then stabilizes at from age 11. A similar trend was seen in the upper face region of Coloured females. Coloured females aged 11 - 13 years showed a decrease in STT at the supraglabella, glabella, nasion and end nasal landmarks.

Data from the current study were compared to that of Stephan and Simpson [23,25] (Table 8). Nine landmarks correspond between the current study and the results by Stephan and Simpson [25]. Differences between $2.1 \mathrm{~mm}$ and $3.0 \mathrm{~mm}$ were seen at the labiale inferius (2.1 
Table 8

Comparison of results from Stephan and Simpson [23] to results of current study.

\begin{tabular}{|c|c|c|c|c|c|c|}
\hline \multirow[t]{2}{*}{ Landmark } & $\begin{array}{l}\text { Current } \\
\text { study }\end{array}$ & $\begin{array}{c}\text { Stephan \& } \\
\text { Simpson } \\
(2008 b) \\
\end{array}$ & \multirow[t]{2}{*}{$\begin{array}{l}\text { Difference } \\
\quad(\mathbf{m m})\end{array}$} & $\begin{array}{l}\text { Current } \\
\text { study }\end{array}$ & $\begin{array}{c}\text { Stephan \& } \\
\text { Simpson } \\
(2008 b) \\
\end{array}$ & \multirow{2}{*}{$\begin{array}{l}\text { Difference } \\
\quad(\mathbf{m m})\end{array}$} \\
\hline & 6 - 11 years & 0 - 11 years & & 12 - 13 years & 12 - 17 years & \\
\hline Glabella & 5.9 & 5.0 & -0.9 & 5.9 & 5.5 & -0.4 \\
\hline Nasion & 5.0 & 8.0 & 3.0 & 5.1 & 8.0 & 2.9 \\
\hline End nasal & 2.2 & 2.5 & 0.3 & 2.2 & 2.5 & 0.3 \\
\hline Midphiltrum & 11.7 & 11.5 & -0.2 & 12.0 & 15.0 & 3.0 \\
\hline Upper lip border & 12.1 & 13.5 & 1.4 & 12.3 & 14.5 & 2.2 \\
\hline Lower lip border & 12.8 & 14.5 & 1.7 & 13.4 & 15.5 & 2.1 \\
\hline Labiomentale & 11.2 & 10.0 & -1.2 & 11.8 & 11.0 & -0.8 \\
\hline Pogonion & 10.4 & 10.5 & 0.1 & 10.7 & 11.5 & 0.8 \\
\hline Beneath chin & 5.7 & 6.5 & 0.8 & 6.0 & 7.5 & 1.5 \\
\hline
\end{tabular}

$\mathrm{mm})$, labiale superius $(2.2 \mathrm{~mm})$, nasion $(2.9 \mathrm{~mm})$ and midphiltrum $(3.0 \mathrm{~mm})$ when comparing STT of the current study to the generalized T-tables of Stephan and Simpson [25] for children aged 12 to 17 . Although these differences are $3 \mathrm{~mm}$ and less, the percentage difference is $56 \%$ at the nasion, $25 \%$ at the midphiltrum, $18 \%$ at the labiale superius and $16 \%$ at the labiale inferius. In terms of percentage, the differences are large and for these landmarks consideration of ancestry in STT datasets should be provided. In children STT values are generally smaller than in adults and differences of $15 \%$ are significant. They may therefore have a considerable effect on the outcome of the facial reconstruction / approximation.

\section{Discussion}

Young children can become victims of crime as they are generally vulnerable. The high number of missing children in South Africa and the many unidentified skeletal remains found regularly in the vast open fields of South Africa [31] motivate the development of methods to legally deal with unclaimed and unidentified remains and the social responsibilities that are associated with it. In this regard, facial reconstruction / approximation is one of the methods to be used to assist in obtaining of information, which can then be followed up with DNA analysis once a possible identification is made.

Facial reconstruction / approximation is based on STT data and the debate in literature concerns the validity of using data specific to populations, sexes and age groups [4-7,11,13$16,20,29,32,34]$. Some authors argued that generalized pooled data can be used, ignoring these possible variants [18,23-25]. However, most authors agree that adult and juvenile STT are different, but do not agree on how age categories should be divided [4,5,11-16, 23]. 
STT data of children are limited [4,5,11,15,23,25,35]. One of the reasons for this is the difficulty in obtaining useful data from living children. Other reasons include the lack of information when performing a retrospective study on patient files with cephalograms or CT images. Therefore, pooling of STT data is common practice to enlarge the sample size in order to improve the reliability and validity of a dataset.

This study has shown that cephalograms from patient files can be useful in obtaining midline facial STT measurements in order to establish a STT database for South African sub-adults. In this case, the patients were seated upright which minimized distortion of the soft tissue of face, an aspect that some researchers have argued causes STT measurement errors due to gravity with patients in supine position as in CT scans [18].

STT standards for South African children per age, sex and ancestry were established. Due to the lack of data for especially the younger age groups, data were also pooled before results were compared between groups. Unfortunately no information was available on the BMI of individuals in the data base.

Despite the sample size of 388 being the largest thus far in South Africa for children, the STT data had to be pooled in age groups in order to perform valid statistical tests, specifically at ages 6 to 9 years. Other reasons for this strategy were that 1) the exact age of juvenile remains presented for facial reconstruction / approximation is rarely known, only the possible age range is provided by the forensic anthropologist; and 2) in literature STT data are also reported in terms of age ranges, however the intervals of these ranges differ significantly. In this regard, the STT data of the current study were subdivided into pooled datasets for comparison to the T-Tables by Stephan and Simpson [18] which only considers age and not ancestry or sex.

Stephan and Simpson [23] suggested 0 - 11 and 12 - 18 years as categories for juvenile data to be pooled. While the division between 11 and 12 years of age is based on the onset of puberty coinciding with large physiological and physical changes in the body [36], the pooling of children aged $0-11$ is questionable. The viscerocranium and overlying soft tissue undergoes extensive changes due to different growth rates in the childhood phase (age 3 - 7), juvenile phase (ages 7 - 10/12) and puberty (females: 10/11 and males 12/13) [36,37] and pooling of STT data of these age groups will result in a too heterogeneous dataset. On the other hand, it is unlikely for a facial reconstruction / approximation to be required of a 1 year old individual. Williamson et al. [13] and Utsuno [14,15] pooled children of less than 9 years, from 10 - 12 years and age 13 and above together. This grouping coincides better with the childhood, juvenile and puberty phases. Manhein et al. [5] and Wilkinson [4] used 6 to 8 years and 9 to 13 years as categories which can 
be problematic as not all girls are in puberty at age 9. A South African study by Philips and Smuts [7] did not take age into account as they included Coloured children and adults ranging from 12 to 71 years in their study, which also creates problems in terms of accuracy and validity.

The T-Tables, or Tallied Facial Soft Tissue Depth Tables, were published by Stephan and Simpson $[18,23]$. These T-Tables are based on human STT data of adults and children $(0-18$ years) from different studies. Stephan and Simpson [18,23] compiled the T-Tables to eliminate measurement errors and uncertainty created by different methodologies and to improve the practical implementation of STT data. Recently, Stephan [25] included more adult data that have been published in the last five years. He revised the work from 2008 with the inclusion of the new data in order to compare the statistics from 2008 to 2013. He also further explored the use of the two new aspects namely the shorth and the 75-shormax. These were introduced to compensate for skewed data which are not normally distributed at some landmarks, measurement error and to provide central tendency statistics that would improve facial reconstruction / approximations [24]. Only minor differences were found when comparing the T-Tables from 2008 to the T-Tables generated in 2013. It was found that 23 of the 25 landmarks differed with less than $1 \mathrm{~mm}$, while the gonion shows the maximum difference between the 2008 and 2013 Tables with $1.7 \mathrm{~mm}$. The shorth is a non-parametric method used to visualize probability mass concentration. The shorth is based on the length of the shortest interval containing a certain fraction of the probability distribution and a point $x$ [38]. The 75 -shormax is the $75^{\text {th }}$ percentile between the shorth and the maximum value [25]. Stephan [25] argues that the shorth and the 75shormax describe central tendencies of skewed facial soft STT better compared to the "normal" (arithmetic) mean. However, as these two descriptors need to be calculated from the raw data of 2000 to 3000 samples, which is not yet available, the T-Tables are currently of more practical use than the shorth and the 75-shormax. Only one new study regarding facial thickness data for children have since been published [39] and as a result, Stephan [25] did not include a review of the sub-adult T-Tables or calculation of the sub-adult shorth statistics in his recent paper. Results of the current study showed that although only the midphiltrum differed with $3 \mathrm{~mm}$ from the Ttables [23], the difference amounted to $25 \%$. Likewise, differences between $16 \%$ and $56 \%$ were seen at the nasion, labiale superius and labiale inferius, while the actual difference in millimetres was less than $3 \mathrm{~mm}$. Therefore, percentages may reflect significant differences in facial appearance rather than measurement differences in millimetres.

Furthermore, the results from the current study indicated that when age groups (ancestry and sex pooled) were compared, statistical significant differences in STT were seen in $30 \%$ of 
landmarks, while STT comparison in terms of sex (ancestry and age pooled) only showed differences at $20 \%$ of landmarks. None of the differences were more than $1 \mathrm{~mm}$. Comparison of STT between ancestry groups (age and sex pooled) showed significant differences at seven out of 10 landmarks with a maximum of $2.12 \mathrm{~mm}$ difference at the midphiltrum (Coloured children $>$ Black children).

Comparison of the different pooling methods show that the division of the STT data into two age groups rather than three $[11,13,15,39]$ rendered results that were less complex to interpret and trends could be better identified. When using age ranges from 6 - 8 year olds and 9 -13 year olds in terms of ancestry and sex [4,5], significant differences were seen at $40 \%$ of landmarks. Actual significant differences in groups were between $1.25 \mathrm{~mm}$ and $1.96 \mathrm{~mm}$. Specific trends were difficult to identify between groups even at landmarks where STT differed significantly. In terms of development, it makes sense to group 6 to 8 year old children together. However, pooling 9 year olds with ages up and including 13 is problematic as puberty plays a role from ages 10/11/12 and onwards. As a result, the 9 to 13 year old group is too heterogonous for comparison, obscuring trends in STT values. While the division between 11 and 12 years by Stephan and Simpson [25] was originally based the density of their data points, it also coincides with on the onset of puberty in females [36]. In the current study, STT data were pooled into age ranges $6-11$ years and $12 \& 13$ years (ancestry and sex pooled) and significant differences were seen between the two age groups at $30 \%$ of landmarks; however none of these landmarks differed with more than $1 \mathrm{~mm}$. Differences below $3 \mathrm{~mm}$ have been described as by Stephan et al. [24] and Stephan [25] as minimal with little practical value.

Subdividing the ages at 10 to create age ranges 6 to 10 years and 11 to 13 years was added to this study because it is before the onset of puberty in either males or females [36]. Comparison between these age groups (sex and ancestry pooled) showed significant differences at $30 \%$ of landmarks with no difference of more than $1 \mathrm{~mm}$ found between groups that were significant. However, when the 6 to 10 year old and 11 to 13 year old groups were analyzed per ancestry, $70 \%$ of landmarks were significantly different. From these landmarks (with significant differences), at least half showed differences of more than $1.2 \mathrm{~mm}$. At the labiale inferius the difference between groups was $1.9 \mathrm{~mm}$ and $1.6 \mathrm{~mm}$ at the pogonion (Coloured children $>$ Black children). Analysis of 6 to 10 year old and 11 to 13 year old groups per sex and ancestry showed that STTs were different at $50 \%$ of landmarks and the differences in millimeters at each were more than $1 \mathrm{~mm}$. At the midphiltrum and labiale inferius the differences were $1.9 \mathrm{~mm}$ and 1.5 $\mathrm{mm}$ respectively. 
From these findings it is recommend that in children, STT data should be pooled as two age groups subdivided at age 10 with ancestry taken into account. Sex should not be considered as it seems not to impact STT with more than $2 \mathrm{~mm}$ at any landmark.

In terms of STT, the current study therefore has shown that ancestry, not sex, impacts on STT of sub-adults. The division of samples into two age groups at age 11 is not desirable as it creates heterogeneous subgroups that show little differences and obscures trends.

The question remains - what is the actual difference in millimeters that will impact on the facial reconstructions / approximations of juveniles? Stephan and Simpson [23] imply that any difference below $3 \mathrm{~mm}$ is of no practical use. The answer may lie in the use of percentages rather than actual differences. A difference of $1.5 \mathrm{~mm}$ between groups at the end nasal landmark with a mean of $2.5 \mathrm{~mm}$ is a $75 \%$ difference; compared to a $13 \%$ difference at the labiomentale with a mean of $11.62 \mathrm{~mm}$. In this example, the difference at the nasion is large and will have a greater impact of the facial appearance compared to the STT difference at the labiomentale.

Despite the large number of children included in the study $(n=388)$, the younger age groups are underrepresented. The underrepresentation of young children is also seen in other studies where pooled data are used to circumnavigate the problem, $(4,5,11,13,15,23,25,39]$. Future studies should aim specifically to increase sample sizes in these groups.

The sample comprised of children from two different geographical origins: Gauteng and Western Cape. Therefore, the results of the current study relate to Black children in Gauteng and Coloured children from the Western Cape and not necessarily to all Black and Coloured children in the remaining parts of South Africa.

Collaboration with forensic artists is necessary to determine when statistical differences are of practical value in terms juvenile facial reconstructions / approximations. Although some past and current forensic cases in South Africa involve children, unfortunately no juvenile material is available to test the STT obtained in the current study. The possibility of using three dimensional reconstructions / approximations of skulls from CT scans of living children is a possibility that could be investigated for future validation studies. 


\section{References}

[1] Report on the neglect and ill-treatment of children. 2011. South African Police Service, Annual Report of the South African Police Service for 2011/2012. SAPS Head Office, Pretoria.

[2] Report on the neglect and ill-treatment of children. 2012. South African Police Service, Annual Report of the South African Police Service for 2012/2013. SAPS Head Office, Pretoria.

[3] Kearney, L., Erasmus, J. Crime in South Africa. [Updated 25 August 2010; cited 20 July 2014] Available from http://www.mediaclubsouthafrica.com/africa/34democracy/developmentbg/117-crime-in-south-africa.

[4] C. Wilkinson. In vivo facial tissue depth measurements for white British children. J. Forensic. Sci. 47 (2002) 459-65.

[5] M.H. Manhein, G.A. Listi, R.E. Barsley, R. Musselman, N.E. Barrow, D.H. Ubelaker, In vivo facial tissue depth measurements for children and adults, J. Forensic Sci. 45 (2000) 48-60.

[6] D. Cavanagh, M. Steyn. Facial reconstruction: Soft tissue thickness values for South frican black females. Forensic. Sci. Int. 206 (2011) 215.e1-215.e7.

[7] V.M. Phillips, N.A. Smuts, Facial reconstruction: utilization of computerized tomography to measure facial tissue thickness in a mixed racial population, Forensic Sci. Int. 83 (1996) 51-59.

[8] M. Adhikari. Contending approaches to Coloured identity and the history of the Coloured people of South Africa. Hist. Compass. AF. 177 (2005) 1-16.

[9] H. Giliomee, B. Mbenga. New history of South Africa, Tafelberg Publishers, 2007.

[10] A. Morris. Missing and murdered, Zebra Press, 2011.

[11] E.R. Dumont. Mid-facial tissue depths of white children: An aid in facial feature reconstruction. J. Forensic. Sci. 31 (1986) 1463-1469.

[12] T.N. Garlie, S.R. Saunders. Midline facial tissue thicknesses of sub adults from a longitudinal radiographic study. J. Forensic. Sci. 44 (1999) 61-67.

[13] M.A. Williamson, S.P. Nawrocki, T.A. Rathbun. Variation in midfacial tissue thickness of African-American children. J. Forensic. Sci. 47 (2002) 25-31.

[14] H. Utsuno, T. Kageyama, T. Deguchi, M. Yoshino, H. Miyazawa, K. Inoue. Facial soft tissue thickness in Japanese female children. Forensic. Sci. Int. 152 (2005) 101-117. 
[15] H. Utsuno, T. Kageyama, T. Deguchi, Y. Umemura, M. Yoshino, H. Nakamura. Facial soft tissue thickness in skeletal type I Japanese children. Forensic. Sci. Int. 172 (2007): 137-143.

[16] T.R. Peckmann, M.H. Manhein, G.A. Listi, M. Fournier. In Vivo Facial Tissue Depth for Canadian Aboriginal Children: A Case Study from Nova Scotia, Canada. J. Forensic. Sci. 58 (2013) 1429-1438.

[17] S. L. Smith, G. S. Throckmorton. Comparability of radiographic and 3D-ultrasound measurements of facial midline tissue depths. J. Forensic. Sci. 51 (2006) 244-247.

[18] C.N. Stephan, E. Simpson. Facial soft tissue depths in craniofacial identification (Part I): An analytical review of published adult data. J. Forensic. Sci. 53 (2008a) 1257-1272.

[19] F. Chen, Y. Chen, Y. Yu, Y. Qiang, M. Liu, D. Fulton, T. Chen. Age and sex related measurement of craniofacial soft tissue thickness and nasal profile in the Chinese population. Forensic. Sci. Int. 212 (2011) 272.e1-272.e6.

[20] N.A.P. Ruiz. Facial soft tissue thickness of Colombian adults. Forensic. Sci. Int. 229 (2013) 160.e1-160.e6.

[21] C.L. Parks, A.H. Richard, K.L. Monson. Preliminary assessment of facial soft tissue thickness utilizing three-dimensional computed tomography models of living individuals. Forensic. Sci. Int. 237 (2014) 146.e1-146.e6.

[22] M. Domaracki, C.N. Stephan. Facial soft tissue thicknesses in Australian adult cadavers. J. Forensic. Sci. 51 (2006) 5-10.

[23] C.N. Stephan, E. Simpson. Facial soft tissue depths in craniofacial identification (Part II): An analytical review of published sub-adult data. J. Forensic. Sci. 53 (2008b) 1273-1279.

[24] C.N. Stephan, E. Simpson, J.E. Byrd. Facial soft tissue depth statistics and enhanced point estimators for craniofacial identification: the debut of the shorth and the 75shormax. J. Forensic. Sci. 58 (2013) 1439-1457.

[25] C.N. Stephan. The Application of the Central Limit Theorem and the Law of Large Numbers to Facial Soft Tissue Depths: T-Table Robustness and Trends since 2008. J. Forensic. Sci. 59 (2014) 454-461.

[26] J.H. Relethford. Race and global patterns of phenotypic variation. Am. J. Phys. Anthropol. 139 (2009) 16-22.

[27] L.L. Cavalli-Sforza, P. Menozzi, A. Piazza. The history and geography of human genes, Princeton University Press, 1994. 
[28] L. Lieberman, R.C. Kirk. What should we teach about the concept of race? Anthropol. Educ. Q. 35 (2004) 137-145.

[29] W.A. Aulsebrook, P.J. Becker, M.Y. Íşcan. Facial soft-tissue thicknesses in the adult male Zulu. Forensic. Sci. Int. 79 (1996) 83-102.

[30] R. Dawson, R.G.Trapp. Basic and clinical statistics, $4^{\text {th }}$ ed., Lange Medical books McGraw-Hill, 2004.

[31] M.Y. Işcan, M. Steyn. The human skeleton in forensic medicine, $3^{\text {rd }}$ ed., Charles Thomas Publisher, Ltd., 2013.

[32] C. Wilkinson, Forensic Facial Reconstruction, Cambridge University Press, 2004.

[34] N.H. de Almeida, E. Michel-Crosato, L.A.S. de Paiva, M.G.H. Biazevic. Facial soft tissue thickness in the Brazilian population: New reference data and anatomical landmarks. Forensic. Sci. Int. 231 (2013) 404.e1-404.e7

[35] S. Codinha. Facial soft tissue thicknesses for the Portuguese adult population. Forensic. Sci. Int. 184 (2009) 80.e1-8-0.e7.

[36] B. Bogin, Childhood, Adolescence, and Longevity: A Multilevel Model of the Evolution of Reserve Capacity in Human Life History. Am. J. Human. Biol. 21 (2009) 567-577.

[37] S. Black, G.J.R. Maat. Principles of physical age estimation, in: S. Black, A. Aggrawal, J. Payne-James (Eds.), Age estimation in the living. A practitioner's guide, WileyBlackwell, 2010, pp. 77-94.

[38] J.H.J. Einmahl, M. Gantner, G. Sawitzki. The Shorth Plot. J. Comput. Graphic. Stat. 19 (2010) 62-73.

[39] H. Utsuno, T. Kageyama, K. Uchida, M. Yoshino, S.O. H. Miyazawa, K. Inoue. Pilot study of facial soft tissue thickness differences among three skeletal classes in Japanese females. Forensic. Sci. Int. 195 (2010a) 165.e1-165.e5.

[40] H.V.R. Knußmann. Anthropologie. Band I. Wesen und Methoden der Anthropologie. Gustav fiacher, Verlag, 1988.

[41] J.C. Kolar, E.M. Salter. Craniofacial anthropometry. Practical measurement of the head and face for clinical, surgical and research use, Charles C Thomas, 1996. 